\title{
A Review of the Pathophysiological Mechanisms Underlying Castration-resistant Prostate Cancer
}

\author{
Fionnuala Crowley' \\ Michelle Sterpi \\ Conor Buckley (D) $^{\prime}$ \\ Lauren Margetich' \\ Shivani Handa (D) \\ Zach Dovey ${ }^{2}$
}

'Department of Internal Medicine, Icahn School of Medicine, Mount Sinai Morningside and West, New York, NY, USA; ${ }^{2}$ Department of Urology, Icahn School of Medicine, Mount Sinai Hospital, New York, NY, USA
Correspondence: Shivani Handa

Department of Internal Medicine, Mount Sinai Morningside and West, 1000 Tenth

Avenue, New York, NY, I0019, USA

$\mathrm{Tel}+\mathrm{I}-917-520-3693$

Email Shivani.Handa@mountsinai.org

\begin{abstract}
Androgen deprivation therapy or ADT is one of the cornerstones of management of locally advanced or metastatic prostate cancer, alongside radiation therapy. However, despite early response, most advanced prostate cancers progress into an androgen unresponsive or castrate resistant state, which hitherto remains an incurable entity and the second leading cause of cancer-related mortality in men in the US. Recent advances have uncovered multiple complex and intermingled mechanisms underlying this transformation. While most of these mechanisms revolve around androgen receptor (AR) signaling, novel pathways which act independently of the androgen axis are also being discovered. The aim of this article is to review the pathophysiological mechanisms that help bypass the apoptotic effects of ADT to create castrate resistance. The article discusses castrate resistance mechanisms under two categories: 1. Direct AR dependent pathways such as amplification or gain of function mutations in AR, development of functional splice variants, posttranslational regulation, and pro-oncogenic modulation in the expression of coactivators vs corepressors of AR. 2. Ancillary pathways involving RAS/MAP kinase, TGF-beta/SMAD pathway, FGF signaling, JAK/STAT pathway, Wnt-Beta catenin and hedgehog signaling as well as the role of cell adhesion molecules and G-protein coupled receptors. miRNAs are also briefly discussed. Understanding the mechanisms involved in the development and progression of castration-resistant prostate cancer is paramount to the development of targeted agents to overcome these mechanisms. A number of targeted agents are currently in development. As we strive for more personalized treatment across oncology care, treatment regimens will need to be tailored based on the type of CRPC and the underlying mechanism of castration resistance.
\end{abstract}

Keywords: castration resistance, prostate cancer, androgen-deprivation therapy, androgen insensitivity, androgen receptor

\section{Introduction}

Apart from skin cancer, prostate cancer is the most common cancer in American men. A reported 33,330 estimated deaths in 2020 makes it the second leading cause of cancer-related mortality in men in the US. The standard of care treatment for localized disease is prostatectomy or radiation with the goal of removing or destroying the malignant cells confined within the prostate capsule. Whereas for locally advanced, recurrent disease after failure of locoregional treatments and metastatic disease the mainstay of treatment consists of androgen deprivation therapy (ADT). The rationale behind this treatment is to create a state of androgen deprivation that induces the apoptotic death of the androgen-dependent tumor cells as famously theorized by Huggins and Hodges. ${ }^{1}$ Unfortunately, despite the early 
efficacy of ADT, after a mean time of 2-3 years prostate cancer patients become refractory to further treatment as the tumors enter into an androgen-liberated state also known as castrate-resistant prostate cancer (CRPC). There are multiple mechanisms implicated in the progression to castration resistance, with the majority involving the androgen receptor (AR). However, there is increasing evidence that the transition from androgen dependance to castrate resistance might rely on alternative growth and survival pathways that either interact with the androgen signaling or are truly AR-independent mechanisms. Interestingly, these driving alterations in pathways may provide important therapeutic targets in androgenindependent prostate cancer. The general aim of this review is to provide an overview of the current evidence regarding both the androgen dependent and independent mechanisms underlying castration resistance.

\section{Androgen Receptor Physiology}

The androgen receptor (AR) gene is located on chromosome $\mathrm{X}$ at locus Y11-12 and codes for a nuclear compound with four distinguishable components: the amino-terminal domain (NDT), DNA binding domain (DBD), a hinge region and ligand binding domain (LBD). ${ }^{2-4}$ In the absence of ligands, the AR remains in the inactive state, bound to heat-shock proteins (specifically HSP90 chaperone complex) in the cytoplasm. The primary AR ligands are dihydrotestosterone (DHT) and testosterone. Upon ligand-binding, AR shifts its conformation and detaches from the HSP90 complex, transports to the nucleus in a homo-dimerized state and attaches to the androgen response element (ARE) in the promoter region of androgen regulated genes. ${ }^{3,5}$

\section{Androgen Deprivation Therapy (ADT)}

AR signaling is central to prostate cancer (PC) oncogenesis. Early studies by Huggins and Hodges in 1941 demonstrated that castration or estrogen injection reduced PSA level in men with prostate cancer. ${ }^{1}$ This observation provided a rationale for ADT which aims to inhibit growth of PC by suppressing serum testosterone to "castrate" levels (defined as $<50 \mathrm{ng} / \mathrm{mL}$ ). ADT was historically achieved with surgical orchidectomy (surgical castration) but can now be performed with medical castration by inhibiting systemic production of androgens via the hypothalamicpituitary-gonadal (HPG) axis.
Gonadotropic releasing hormone $(\mathrm{GnRH})$ is released from the hypothalamus in a pulsatile manner under physiologic conditions and stimulates the release of luteinizing hormone (LH) from the pituitary, which in turn stimulates testicular Leydig cells to produce testosterone. By contrast, a steady state concentration of GnRH has an inhibitory effect on the pituitary and blocks testosterone production via the HPG axis. Thus, the therapeutic administration GnRH agonists (leuprolide, goserelin, buserelin, triptorelin) and antagonists (degarelix) shuts down androgen production via the HPG axis.

Accounting for approximately $10 \%$ of systemic androgen production is the adrenal gland, wherein androgen precursors (pregnenolone, DHEA) are converted to testosterone via adrenal cytochrome P450 pathways. Abiraterone acetate is a selective, irreversible inhibitor of CYP17, and inhibits androgen production in the adrenal glands, testes and prostate-tumor tissue. The STAMPEDE trial showed that addition of abiraterone and prednisolone to ADT in men with locally advanced or metastatic prostate cancer significantly improved overall failure-free survival compared to ADT alone. ${ }^{6}$

Furthermore, combined androgen blockade (CAB) consists of ADT plus antiandrogens (enzalutamide, apalutamide, darolutamide). Antiandrogens interfere directly with AR signalling by blocking binding to androgen ligand, inhibiting nuclear translocation and association with nuclear DNA. A recent study by Sternberg et al showed enzalutamide plus ADT enhanced median overall survival for men with nonmetastatic CRPC. ${ }^{7}$

\section{Castration Resistance}

Early response to ADT is usually phenomenal, with 80 $90 \%$ of cases of metastatic disease achieving rapid decline in PSA. ${ }^{8}$ However, metastatic disease that initially responds to ADT almost always eventually exhibits secondary resistance. ${ }^{9}$ Castration resistance can be defined either clinically (as the occurrence of new metastasis or progression of preexisting disease) or biochemically as a $25 \%$ increase from the PSA nadir (considering an initial value of $\geq 1 \mathrm{ng} / \mathrm{mL}$ ) in men with serum testosterone of $<50$ $\mathrm{ng} / \mathrm{mL}$, with a minimum rise of $2 \mathrm{ng} / \mathrm{mL}$, which must be confirmed with a second value obtained $1-3$ weeks later without radiological evidence of metastases. ${ }^{10,11}$

Understanding of castration-resistant PC (CRPC), previously called hormone refractory $\mathrm{PC}$, has undergone a paradigm shift as elucidation of molecular mechanisms of castration-resistance reveals the continuing role of the androgen axis in the propagation of CRPC. 


\section{AR-mediated Mechanisms of Resistance in CRPC}

These mechanisms will be reviewed in this section under the following headings: AR amplification and overexpression, AR splice variants, AR mutations and promiscuity, posttranslational regulation of $\mathrm{AR}$, coactivators or corepressor modification and intratumoral steroid hormone synthesis. Figure 1 illustrates the different AR dependent mechanisms along with potential therapeutic targets.

\section{AR Amplification and Overexpression}

Gene amplification is defined as an increase in gene copy number beyond the normal diploid copy number. AR amplification (Xq11-q13 region) is present in $20-31 \%$ of patients with CRPC. ${ }^{12-14}$ AR amplification was present in none of the benign prostatic hyperplasia (BPH) samples, only $2 \%$ of the primary PC tumor and $23.4 \%$ of CRPC tumors on FISH analysis. ${ }^{13}$ Evaluation of samples from the same case have shown that AR gene amplification only occurs when the tumor enters a castrate-resistant state and is associated with a twofold increase in AR mRNA levels. ${ }^{14,15}$ Chen et al compared AR protein levels in CRPC samples to multiple isogenic tumor xenograft models using microarray-based profiling and found increased AR expression in CRPC cells. ${ }^{16}$ In addition, CRPC is also marked by enhanced $A R$ protein stabilization due to posttranslational modifications ${ }^{17}$ and interaction with protein chaperones, for example, the heat shock protein (HSP) family. ${ }^{18}$ The end-effect of these mechanisms is to empower PC cells with enhanced sensitivity to minimal levels of circulating androgens allowing them to recommence androgen-mediated growth despite being in an androgen-depleted milieu.

\section{Splice Variants}

AR splice variants encode a modified form of AR protein with an absent C-terminal LBD but an intact N-terminal domain and a partial or complete DBD which is still functionally capable of interacting with DNA and AR coreceptors. ${ }^{19,20}$ Thus, despite being unable to bind ligands, these truncated proteins are constitutively active as transcription factors, promoting expression of target genes activating downstream AR signaling pathways. ${ }^{9}$ Out of the seven AR variant transcripts described in literature (ARV1-ARV7), AR-V1 and AR-V7 are most often expressed in CRPC. ${ }^{19}$ AR splice variants are of particular interest in CRPC with resistance to enzalutamide and abiraterone, which occurs as primary resistance in 20 to $40 \%$ of cases and secondary resistance in virtually all cases despite initial response. ${ }^{21-23}$ A plausible mechanism of resistance is suggested by the fact that AR splice variants lack an LBD and both enzalutamide and abiraterone

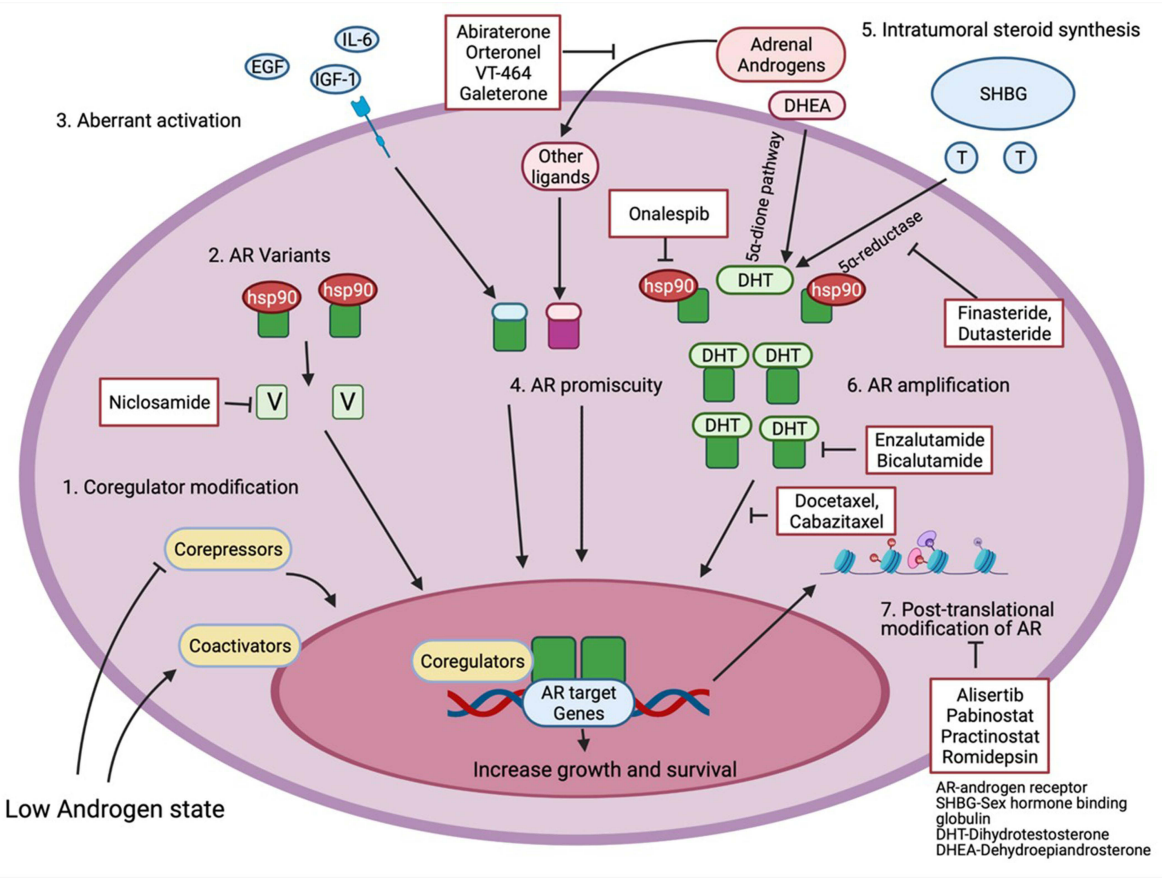

Figure I Androgen receptor mediated mechanisms of castration resistance in prostate cancer along with potential therapeutic targets. Made with Biorender.com. 
exert their action via binding to the LBD. Multiple therapeutic agents targeting $\mathrm{AR}$ variants by enhancing their degradation (eg niclosamide or selective AR degraders such as UT-155 and UT-69), inhibiting their synthesis (eg onalespib, quercetin, thailanstatins), binding to N-terminal domain (eg EPI-001) or DBD (eg VPC-14,449) or impeding the action of AR variant coactivators are currently under investigation. $^{24}$

\section{Mutations}

Another mechanism of castration resistance is prostate cancer is gain of function mutations in the AR. As with splicing variants, clinically relevant point mutations predominantly affect the ligand-binding domain. However, rather than conveying constitutive activation, AR gain of function mutations have been shown to induce enhanced sensitivity to low levels of androgens, affinity for nonandrogen ligands (glucocorticoids, progestins, estrogens, dehydroepiandrosterone) and even antagonist-to-agonist switching. ${ }^{5,25-27}$ One such mutant is AR T877A which not only binds to androgens, but also to other hormones such as estrogen and progesterone as well as AR antagonists. $^{5,25,27}$ AR T877A has only been identified in CRPC patients, but not hormone-naïve patients, supporting the role of T877A in developing castrate-resistance following prolonged exposure to $\mathrm{ADT}^{28,29}$ In fact, Suzuki et al found that expression of this mutant in CRPC patients was associated with a remarkable fall in prostate-specific antigen after withdrawal of antiandrogen therapy. ${ }^{27}$ In a similar fashion, the AR-LBD missense mutation (F876L) results in agonists activity from the AR antagonists ARN-509 and enzalutamide. ${ }^{30}$

\section{Posttranslational Regulation of AR}

Posttranslational regulation of AR represents an important molecular mechanism for enhancing AR signaling - these processes include acetylation, methylation, phosphorylation, SUMOylation and ubiquitination. ${ }^{31}$ The functions of these processes include: dictating AR protein stability and degradation, intracytosolic AR localization, controlling transcriptional function of AR and modulating the expression of AR target genes expression. ${ }^{32}$ The role of phosphorylation, methylation and acetylation is generally to augment the transcriptional function of AR with only a small number of the 19 phosphorylation sites of AR inhibiting transcriptional activity. ${ }^{32}$ Protein kinase A, $\mathrm{B}$ and $\mathrm{C}$, mitogen-activated protein kinase, activated CDC42 kinase 1 and src-family kinases have all been incriminated in AR phosphorylation. ${ }^{33}$ The phosphorylation of $\mathrm{AR}$ at serine 81 (S81), located in the $\mathrm{N}$ terminal domain of AR, regulates AR protein stability, cellular activation and transactivation. ${ }^{32} \mathrm{~S} 81$ is the most highly phosphorylated site on AR with phosphorylation occurring in response to androgens. Phosphorylated S81 is decreased after castration corresponding with loss of AR activity, but is highly expressed in CRPC) tumors with one study suggesting its association with AR resurrection in CRPC. $^{34} \mathrm{~A}$ number of cyclin-dependent kinases are involved in phosphorylation of S81, with inhibition of these kinases leading to a reduction in the process. ${ }^{32}$ Phosphorylation of serine 308 (S308) and serine 791 (S791) negatively regulates the transcriptional activity of $\mathrm{AR}^{32,35}$ Ubiquitination also promotes AR transcriptional activity. ${ }^{33}$ It was found that Siah2, a E3 ubiquitin ligase contributes to CRPC, by regulation of androgen receptor activity with Siah2 inhibition promoting PC (PC) regression following castration. ${ }^{36}$ Finally, SUMOylation, which leads to binding of small ubiquitin like modifiers(SUMO) to AR, generally results in repression of AR transcriptional activity. ${ }^{33}$ When chemical castration fails, targeting the above pathways of AR posttranslational- modification may represent a promising treatment strategy for CRPC.

\section{Coactivators or Corepressor Modification}

AR's interaction with coregulators is key in the development of CRPC. AR acts as a transcription factor in collaboration with a number of "coactivators" and "corepressors" which control its transcriptional activity. ${ }^{37}$ Greater than 150 molecules are known to influence AR's transcriptional activity. ${ }^{38}$ These coregulators have a wide variety of roles: as previously mentioned, they modulate other proteins through phosphorylation and epigenetic alterations, act as molecular drivers, interfere with RNA splicing and stimulate transcriptional pathways. ${ }^{39,40}$ Critically, these coregulators facilitate transcriptional function of AR even under an androgen-depleted milieu and have thus been implicated in development of CRPC. ${ }^{37}$ CBP/P300, p160/SRC, and GATA2 are examples of coactivators of AR. ${ }^{41-43}$ Interplay with a coactivator results in aberrant stimulation of AR, leading to heightened transcriptional response and consequently increased $\mathrm{PC}$ growth. ${ }^{39}$ When inhibited, AR expression is decreased and in vitro and in vivo studies, the use of small molecule inhibitors of these coactivators leads to reduction in PC growth. ${ }^{42-44}$ Components of the steroid receptor coactivator family (SRC) are heavily expressed in CRPC. ${ }^{38,45}$ 
Phosphorylation of SRC1 by a number of different mechanisms enables it to activate AR transcription in the absence of androgens. ${ }^{46}$ Corepressors, such as NcoR 1 and NcoR 2 have the opposite effect on AR transcription activity. A preclinical study found that following treatment with bicalutamide, an antiandrogen, NCoR recruitment was reduced or absent in cells with increased AR receptor protein. ${ }^{16}$ Corepressors are frequently decreased in CRPC. ${ }^{47}$ This imbalance of control, arising from increased activity of coactivators and reduced influence of corepressors leads to a progrowth state, which is androgen independent - in essence facilitating development of CRPC.

Ligand independent activation of AR signaling can also be achieved by interactions with other cytokines, growth factors and hormones. In an androgen-depleted state, IL-6 can potentiate the existing androgens as well as self-activate $\mathrm{AR}$ at about half of its functional capacity. $^{48,49}$ Insulin like growth factor-1 (IGF-1), epidermal growth factor (EGF) and keratinocyte growth factor (KGF) have also been found to directly activate the AR in the absence of androgens ${ }^{50}$ with use of bicalutamide completely inhibiting activation of AR by these factors. ${ }^{50}$ In addition, elevated IGF binding protein corresponds to faster progression to CRPC and lower survival in men with metastatic PC. ${ }^{51}$

\section{Intratumoral Steroid Hormone Synthesis}

PC employs intracrine androgen biosynthesis as another method to allow growth in androgen depleted conditions. Hormonal therapy which lowers circulating testosterone and thus depletes intraprostatic/intratumoral DHT (dihydrotestosterone) (which has a much more potent effect on AR) has been the mainstay treatment of advanced PC for many years. ${ }^{52}$ PC cells contain all the necessary components for androgen biosynthesis, with levels of many key enzymes being increased in recurrent PC. ${ }^{53}$ The source of androgens in prostatic tissue after ADT involves intracrine production within the gland, converting adrenal androgens to DHT. It was found that DHT measurements in prostatic samples after androgen deprivation therapy remained at $25 \%$ the amount measured before anti-hormone treatment. ${ }^{54}$ Montgomery et al found that this intracrine steroidogenesis occurs not only in primary PC tumors, but also in distant metastases. ${ }^{55}$ Moreover, CRPC metastatic sites are marked by an augmented expression of steroidogenic genes such as CYP17A1-19A1, HSD3B1-17B3, etc. ${ }^{55}$ The alternate $5 \alpha$-dione pathway is the major route for DHT synthesis in CRPC. This pathway catalyzes the conversion of dehydroepiandrosterone (DHEA) and androstenedione to DHT while bypassing testosterone completely. $^{52}$ Enzalutamide is an AR antagonist. Enzalutamide resistant cell lines were found to have increased expression of genes involved in androgen biosynthesis. ${ }^{56}$

\section{Nonandrogen-mediated Mechanisms of Resistance FGF Signaling}

The fibroblast growth factor (FGF) pathway is central to organogenesis and oncogenesis as it cross-links the epithelial and mesenchymal compartments. ${ }^{57}$ The function of the interaction between these two domains is to mediate the regulatory effects of androgens and, therefore, prostatic development, function and tissue homoeostasis. ${ }^{58,59}$ The FGF axis might be implicated in the reciprocal communication between epithelium and mesenchyme via a paracrine crosstalk through a diverse set of ligands and receptors, ultimately leading to the proliferation and differentiation of both the epithelium and the stroma. ${ }^{60,61}$

FGF ligands signal through four analogous tyrosine kinase receptors, appointed FGFR1 to 4, piloting the subsequent induction of myriad signal transduction channels, such as the Erk, MAPK, and PI3K-Akt pathways. ${ }^{57}$ Alternative splice variants of FGFRs are distributed between the epithelium and the stroma and have very different binding and mediating capacities. In fact, FGF7 and FGF10, expressed exclusively by the mesenchyme in benign prostate tissue, can induce prostate organogenesis independently of the AR, with mitogenic action selective for prostate epithelium but not the stroma. ${ }^{62,63}$ Both ligands usually bind preferentially to the FGFR2 IIIb isoform (FGFR2b), while FGF7 also has affinity for the IIIb splice variant of FGFR. ${ }^{57,64}$

Conversely, a disruption of the tissue and cell type specific expression of the FGF family leads to alterations in the homeostatic balance that promotes neoplastic transformation, often found in prostate tumors. In further detail, autocrine expression of FGF6 and FGF8 is present in the majority of PCs, with increased expression of FGFR1 typically identified in poorly differentiated prostate adenocarcinoma. $^{65}$ Moreover, the abovementioned FGFRIII-b isoform is often lost or alternatively spliced to FGFR2IIIc in epithelial cells during progression to malignancy. The latter isoform does not recognize FGF7 and instead binds strongly to FGF2, a component of the 
FGF family incriminated in the progression and spread of solid cancers. ${ }^{66-68}$ In the study by Naimi et al, it was noted that FGFR2III-b isoform was drastically reduced in $60 \%$ of androgen responsive tumors and $90 \%$ of castrate resistant tumors with a definite association between a decreased FGFR2(IIIb) expression and Gleason score. ${ }^{68}$ In addition, the switch from epithelial-type FGFR2IIIb to mesenchymal-type FGFR2IIIc, along with ectopic FGFR1 expression, has been hypothesized to be a manifestation of an epithelial-to-mesenchymal transition (EMT), a phenomenon strongly linked with tumor progression and, more specifically, sarcomatoid carcinoma. ${ }^{69-72}$ Lastly, as observed by Memerzadeh et al in their model, it appears logical to assume that the ability of FGF-10 to help normal prostate cells thrive in an androgen-starved environment translates into an FGF10-induced survival of prostatic cancer cells through the activation of a paracrine mesenchymal AR signaling, despite castrate levels of androgen. $^{60}$

\section{TGF- $\beta$ Pathway}

The transforming growth factor- $\beta$ (TGF- $\beta$ ) family comprises TGF- $\beta$ s, bone morphogenetic proteins (BMPs), activins and related proteins. There are three different TGF- $\beta$-secreted cytokines, $\beta 1, \beta 2$ and $\beta 3$, all of which operate through the same receptor signaling systems. ${ }^{73}$ Their role in the regulation of cellular functions is a complex one and highly dependent on the cell context. In normal prostate cells, TGF- $\beta$ signaling has been known to have an inhibitory effect on proliferation and differentiation linked to castration-induced apoptosis. ${ }^{74}$ Paradoxically during tumorigenesis, TGF- $\beta$ s, and particularly TGF- $\beta 1$ and TGF- $\beta 3$, can instead have oncogenic activities by stimulating angiogenesis, ${ }^{75}$ suppressing the immune system, ${ }^{76}$ and stimulating invasion and metastatic potential. $^{77,78}$

TGF- $\beta$ s exerts their action trough a well-documented SMAD-dependent mechanism, as well as a SMADindependent one, through mediators such as and PI3K/ AKT23, mitogen-activated protein kinase (MAPK), LIM kinases and transforming protein RhoA. ${ }^{79,80}$ Interestingly, these different mediators of the TGF- $\beta$ messaging cascade might explain the dual nature of TGF- $\beta$ multifunctional cytokines. The SMADdependent pathway likely has an anti-oncogenic effect in initial stages of PC and then switches towards nonSMAD pathways which at as pro-oncogenic in late stages of the disease. ${ }^{81}$ Alteration in the activation of the latter is associated with acquired resistance selective for TGF- $\beta 1$ 's antiproliferative effects, ${ }^{82,83}$ while maintaining sensitivity for its inducement toward extracellular matrix (ECM) disintegration and EMT. As discussed by Jones et al, the abnormally high level of TGF- $\beta$ is generally linked with a concomitant absence of the T $\beta$ RI and T $\beta$ RII receptors, which are key in conserving the physiologic role of TGF- $\beta$ pathway. ${ }^{81}$ Their loss during tumor progression permits the cells to escape the growth constraints normally imposed by TGF- $\beta$ and shifts the balance toward a pro-oncogenic outcome. Moreover, studies like the one conducted by Song et al showed how the loss of T $\beta R I I$ is key in the androgen-mediated regulation of TGF- $\beta$ signaling in PC cells. ${ }^{84}$ In fact, DHT stimulation can interrupt the TGF- $\beta$ messenger cascade by downregulating the synthesis of T $\beta$ RII via Sp1/3's attachment to the TRRII promoter region, affecting its transcriptional and possibly translational control. ${ }^{84}$ Notably, the TGF- $\beta$ promoter was shown to contain six androgen-response elements which have a strong foothold in the androgen regulation of TGF- $\beta 1$ transcription. According to the growing evidence, the AR signaling pathway might be constitutively activated in advanced prostate carcinoma, probably by AR imitating the configuration of ligand-activated $\mathrm{AR}$ in the absence of androgen. Ultimately, this androgen-independent activation of the AR pathway may suppress TGF- $\beta$ messaging by inhibiting the genesis of T $\beta$ RII, constituting a possible mechanism operating in androgen refractory PC. In addition, the loss of tumor suppression PTEN might promote liberation from androgen by inhibiting the activation of SMAD3 by an AR-independent mechanism by sequestering SMAD3 from T $\beta \mathrm{RI}^{85,86}$

\section{RAS/MAPK Pathway}

The RAS-MAPK pathway is a downstream mediator to the cellular responses to different growth signals and is often deregulated in human cancer, leading to a cascade of successive phosphorylation steps that culminates in the activation of mitogen-activated protein kinases (MAPKs). ${ }^{87,88}$ Both the overexpression and mutational activation of c-Ras are well-known agents in human oncogenesis and correlate with disease progression ${ }^{89}$ Similarly, elevated levels of activated MAP kinase are associated with an increasing Gleason score and prostate tumor stage $^{90}$ and ERK1/2 activation is essential in causing RAF-induced AR suppression, supporting MAPK signaling in $\mathrm{PC}$ advancement. ${ }^{89,91}$ 
Overall, the RAS/MAPK signaling was observed to be activated in $43 \%$ of primary PC samples and $90 \%$ of metastatic samples. ${ }^{92}$ Activation of the MAPK signaling via $B$-Raf (V600E) expression can independently induce basal (p63+) cell proliferation and expression of EMT markers ${ }^{93}$ that result in abnormal proliferation and basaloid hyperplasia. In particular, the conditional loss of function of PTEN combined with the activation of B-Raf resulted in prostate tumors that were innately resistant to castration and widely metastatic, as observed by Wang et al in mouse models. ${ }^{94}$ Moreover, this pathway has a substantial role in promoting CRPC metastasis in DU145 PC cells and, conversely, treatment with a MEK inhibitor or knockdown of either ERK1 or ERK2 reduced these cells' sphere-forming ability. ${ }^{89,95}$ In particular, DU145 cells, with known low metastatic potential, were employed in a xenograft metastasis model by Yin et al to demonstrate how the expression of Ras-mediated effector pathway differentially stimulated metastasis in different organs, with RasV12G37 expression inducing bone metastasis. ${ }^{96}$ Further preclinical evidence supports that this pathway can lead to cooperation with other pathways previously mentioned, such as the TGF and FGF signaling - toward the progression of LNCaP cells to hormonerefractory disease, rendering them hypersensitive to low levels of androgen. Interestingly, the study conducted by Bakin et al proved how the dominant negative form of Ras (RasN17), and thus the attenuation of Ras signaling, leading to the restoration of androgen responsiveness in castrate resistant $\mathrm{C} 4-2 \mathrm{PC}$ cells. ${ }^{97}$ In this study, the expression of RasN17 in combination with bicalutamide leads to a nearly complete growth inhibition of RasN17 cells, with the inhibition of MAPK signaling in the highly tumorigenic $\mathrm{LNCaP}$ cell line causing tumor regression in surgically castrated mice. This suggests that the MAPK arm of Ras signaling may be an appropriate target for treatment of CRPC. Likewise, it is plausible to assume that it can be cotargeted with the PTEN/PI3K/AKT axis, given its conjunct action in upregulating c-myc38, to prevent the development of metastatic PCs.

\section{Wnt- $\beta$ Catenin Pathway}

The canonical Wnt/ $\beta$-catenin signaling pathway, which is known to play a central role in embryogenesis, has emerged as a culprit in progression to late-stage PC as well as correlating with aggressive disease, higher Gleason score and PSA levels. ${ }^{98}$ The role of the active Wnt $/ \beta$ catenin pathway in PC progression is manifold and involves neuroendocrine differentiation, induction of epithelial to mesenchymal transformation, bone metastasis, resistance to androgen deprivation therapy and complex interaction with other molecules/pathways such as the PTEN, PI3K and mTOR. ${ }^{99-102}$

Under physiologic conditions, $\beta$-catenin exists as a component of the E-cadherin-based cell surface adherens junction. ${ }^{103}$ Upon disruption of the cell surface complex, $\beta$-catenin is released into the cytoplasm where it is sequestered and phosphorylated by APC complex which marks it for ubiquitination. However, in the presence of activated Wnt signaling pathway, this $\beta$-catenin molecule escapes degradation and translocates into the nucleus where it interacts with TF/LEF-1 and upregulates the transcription of several oncogenes such as Myc and cyclin D1 amongst others. ${ }^{104}$ Moreover, $\beta$-catenin acts as a coactivator of the androgen receptor, the two colocalizing into the nucleus, where $\beta$-catenin aids in androgen-independent transcription of $\mathrm{AR}$ target genes ${ }^{105}$ Interestingly, AR overexpression in CRPC is seen to co-exist with an activated $\mathrm{Wnt} / \beta$-catenin signaling pathway, whereas this pathway is inhibited in the presence of normal levels of androgen or AR agonists. ${ }^{106}$ In addition, the expression of lymphoid enhancer binding factor-1 or LEF-1, the central effector protein in $\mathrm{Wnt} / \beta$-catenin signaling pathway, is augmented by a 100 -fold in androgen-independent LNCaP variant cells and is associated with AR overexpression. Alternatively, the absence of LEF-1 is shown to downregulate $\mathrm{AR}$ expression and decrease the invasiveness of androgen-independent PC cells. ${ }^{107}$

Wnt/ $\beta$-catenin pathway plays a two-pronged role; it helps sensitize PC cells to minimal levels of androgen and abets AR signaling in the castrated state. However, once PC cells lose their prostatic differentiation, Wnt $/ \beta$ catenin signaling switches its role to downregulate AR expression and promotes neuroendocrine differentiation. ${ }^{108,109}$ The latter is achieved by a crosscommunication between Wnt and Akt, whereby activated Wnt pathway phosphorylates Akt resulting in proteosomal degradation of AR. ${ }^{110}$ Ciarlo et al have proposed a model wherein Akt activation results in hn-RNP and $\beta$ catenin phosphorylation and their transcriptional activities subsequently induce NE differentiation. ${ }^{111}$ Neuroendocrine PC is characterized by heightened expression of several downstream targets of the Wnt signaling pathway such as FOXA2, SOX2, CD44, amongst others. ${ }^{112-114}$ Yang et al demonstrated that LNCaP cells cultivated in an androgen-devoid medium 
and transfected with $\beta$-catenin differentiated into $\mathrm{NE}$ cells characterized by increased expression of neuronspecific enolase and chromogranin-A. ${ }^{115}$

Another seminal impact of Wnt signaling is its role in inducing epithelial to mesenchyme transformation whereby PC cells shed their epithelial characteristics and gain metastatic potential. This is achieved by a multitude of events such as upregulation of $\mathrm{N}$-cadherin coupled with downregulation of E-cadherin, induction of transcription factors such as TWIST, SNAIL and SLUG, and expression of matrix metalloproteinases that degrade extracellular matrix and aid in invasiveness. ${ }^{116-119}$ Further, Zhang et al have attributed the self-renewal properties of cancer stem cells, at least in part, to $\mathrm{Wnt} / \beta$-catenin signaling in high TERT expression PC cells ${ }^{120}$ Given the multilayered involvement of the $\mathrm{Wnt} / \beta$-catenin pathway in PC progression, small molecular inhibitors targeting a combination of mechanisms that activate this pathway are emerging as promising therapies.

\section{Hedgehog Signaling Pathway}

Another developmental signaling pathway that is central to organogenesis and homeostasis, the hedgehog (Hh) pathway, has been incriminated in propagation of CRPC. Hh pathway is active in urogenital sinus epithelium, the site of prostate development during embryogenesis and is reactivated during carcinogenesis. ${ }^{121}$ When Hh proteins binds to its receptor ie, patched $(\mathrm{PTCH})$, a G-protein coupled like receptor called smoothened (Smo) is unsuppressed and leads to stimulation of Gli transcription factors culminating in overexpression of culprit genes. ${ }^{122}$ The Gli family proteins also interact with AR at its Tau5 domain and induce AR transcription in an androgen-deprived state. Shaw et al have demonstrated augmented expression of $\mathrm{Hh}$ signaling proteins in androgen independent LNCaP cell lines which were successfully suppressed by cyclopamine, a known Hh signaling inhibitor. ${ }^{123}$ They also exhibited increased expression of PTCH in circulating tumor cells derived from patients with CRPC as compared to normal individuals. Moreover, the levels of PTCH were strongly associated with the length of exposure to androgen-deprivation therapy.

Hh signaling has a multifaceted role in metastasis including promotion of angiogenesis by upregulating angiopoietin-1 and downregulating angiopoietin-2, ${ }^{124}$ inducing epithelial to mesenchymal transition as well as rendering stemness as characterized by expression of stem cell markers like nestin and Bmi-1. ${ }^{125} \mathrm{Hh}$ pathway is both necessary and sufficient for CRPC growth and offers an attractive therapeutic target. Itraconazole, an SMO inhibitor, has been shown to inhibit Hh signaling in CRPC and clinical trials assessing the role of Hh inhibitors vismodegib and sonidegib are underway. ${ }^{126}$

\section{Role of Cell-surface Adhesion Molecules (CAMs)}

When it comes to cancer progression, cell surface adhesion molecules go above and beyond their basic function of cell-cell attachment and serve a critical role in cellular proliferation, motility, invasiveness and EMT as their interactions with extracellular matrix become dysregulated. Integrins are one such family of CAMs that stand out with respect to differential expression in different stages of PC progression. Out of the 24 sub-units of the integrin family (18 $\alpha$ and $8 \beta$ ); the $\alpha \mathrm{IIb}, \beta 1, \beta 3$, and $\beta 6$ subunits and their heterodimer forms such as $\alpha \mathrm{V} \beta 6, \alpha \mathrm{V} \beta 3$, $\alpha 3 \beta 1, \alpha 6 \beta 1$ are selectively overexpressed in invasive carcinomas whereas most other phenotypes are lost. ${ }^{127,128}$ The $\alpha 6 \beta 1$ integrin acts as a laminin receptor and advances cellular migration whereas the $\alpha 6 \beta 4$ integrin which strengthens the hemidesmosomal bonds between ECM and cellular skeleton is often lost in the progression from intra-epithelial neoplasm to invasive cancer. ${ }^{129}$ Quaglia et al have demonstrated that $\alpha \mathrm{V} \beta 3$ integrin-rich extracellular vesicles originating from PC cells induce neuroendocrine differentiation whereas the $\alpha \mathrm{V} \beta 6$ integrin is limited to areas of adenocarcinoma and is upregulated in areas of bony metastasis. ${ }^{127}$ Similarly, Lu et al have discovered that $\alpha \mathrm{V} \beta 6$ is involved in androgen-independent nuclear localization and signal transduction of androgen receptor via JNK-1 pathway. $\alpha \mathrm{V} \beta 6$ also results in overexpression of survivin which in turn supports the growth of detached $\alpha \mathrm{V} \beta 6$-expressing PC cells and leads to a vicious cycle of CRPC propagation. ${ }^{130}$ With this in mind, multiple integrin inhibitors including monoclonal antibodies such as abituzumab (anti- $\alpha v$ antibodies), etaracizumab (anti- avß3 antibody), campothecins and statins that target $\alpha v \beta 3$, aptamers against $\alpha 6 \beta 4$ as well as RGD sequence containing peptides as well as nonpeptides that bind to integrins, are being developed as therapeutic targets. ${ }^{131}$

Besides integrins, another member of the cadherin superfamily, protocadherin 7 , has been shown to be amplified in CRPC and modulates phosphorylation of ERK, Akt and $\mathrm{RB}$ thereby powering tumor propagation. ${ }^{132}$ Epithelial cell adhesion molecule (EpCAM) has also been associated 
with metastatic progression in CRPC by fueling the PI3K/ Akt/mTOR pathway. ${ }^{133}$ Furthermore, overexpression of the $\beta$ subunits of the lesser known voltage sensitive sodium channel-associated cell adhesion molecules is yet another mechanism that makes PC cells more adherent to vitronectin and aids in invasion through extracellular matrix. $^{134}$

\section{Role of G-protein-coupled Receptors (GPCR)}

Increased expression and activation of GPCRs and their ligands is linked to tumor growth in PC. ${ }^{135}$ Many of the GPCRs make up the hypothalamus-pituitary-gonadal (HPG) axis, which is central to the pathophysiological progression of PC. The key hormone-responsive GPCRs involved in the regulation of $\mathrm{PC}$ are gonadotropin-releasing hormone receptor (GnRHR), luteinizing hormone receptor (LHR), follicle stimulating hormone receptor $(F S H R)$, relaxin family peptide receptor (RXFP), growth hormone secretagogue receptor (GHSR), and kisspeptin receptor (GPR54). ${ }^{136}$

While GnRHR plays a pivotal antitumor role, such is not the case with other receptors in the HPG axis. The Gs protein coupled LHR has been implicated in in-situ steroid production within androgen sensitive as well as insensitive PC cells via the cAMP/PKA/ERK1/2 pathway that stimulates the function of target genes such as CYP17A1, STAR and AKR1C1-C3. ${ }^{137}$ Moreover, LHR also prevents apoptosis by upregulation of $\mathrm{Bcl}$ and $\mathrm{Bcl}-\mathrm{X}_{\mathrm{L}}$ while decreasing the expression of Bad and Bax via the PI3K/Akt cascade. ${ }^{138-140}$ Similarly, the FSHR also promotes steroidogenesis, but additionally participates in the progression of bone metastasis by positively modulating osteoclastic activity as well as promoting angiogenesis. ${ }^{141}$ Another GPCR - the relaxin receptor stimulates cellular proliferation, invasion, and blood vessel formation in CRPC via the PI3K/ Akt/ $\beta$-catenin pathway. ${ }^{142,143}$ Akin to GnRHR, the kissipeptin receptor also suppresses tumor growth via $\mathrm{Gq} / \mathrm{phospholipase-}$ $\mathrm{C} /$ calcium-mediated signaling ${ }^{144}$ whereas the GHSR plays a biphasic role by inhibiting cell growth at higher concentration and promoting cellular proliferation at lower levels. ${ }^{145}$ Besides, activation of GPCRs by other ligands such as endothelin and bradykinins have also been implicated in CRPC progression. ${ }^{146,147}$

\section{The JAK-STAT Pathway}

Cell proliferation, migration, and other major cellular functions are highly regulated via cytokines. Among cytokines, interleukin-6 (IL-6) is of particular interest for PC development. IL-6 levels have been shown to be higher in PC patients compared to their counterparts. $^{148,149}$ IL-6 plays a role in regulating the immune response as well as cell growth via activation of Janus kinase (JAK)/signal transducer and activator of transcription (STAT) pathway and cross-talk with MAP kinase, PI3K, and other cellular pathways. ${ }^{150}$ Both BRCA1 and AR can bind to STAT3 in PC cells and activate the downstream JAK/STAT channel upregulating target genes such as VEGF, Bcl-2, Bcl-xl, survivin and Mcl-1, acting as a retardant for apoptosis and enabling angiogenesis. ${ }^{151}$ IL-6 also works as an autocrine growth factor that promotes PC cell growth. ${ }^{152,153}$

From the immunological perspective, the JAK/STAT pathway is vital to PD-L1 expression as an upstream regulator. It is well-known that overexpression of PD-L1 allows tumor cells to evade cell death by T-cell immune responses. $^{154,155}$ In addition, the antitumor pathway of natural killer (NK) cells can also be inhibited via PD-L1 expression by blocking NKG2D ligands on the cell's surface. In CRPC, there is increased resistance to natural killer (NK) cell-mediated cytotoxicity as IL-6 dysregulates PD-L1 and NKG2D ligand levels. ${ }^{156}$ In fact, blocking the JAK/STAT pathway has shown to confer increased susceptibility to NK-cell mediated death in CRPC cells. ${ }^{157}$

\section{Role of MicroRNAs}

MicroRNAs (miRNAs) are small noncoding 21 to 23 nucleotide base pair RNA molecules that act as transcriptional and posttranscriptional regulators of gene expression via base-pairing with messenger RNAs. ${ }^{158}$ About $60 \%$ of all human genes are regulated by miRNAs and miRNAs interact with a number of the pathways discussed above. ${ }^{159}$ In prostate cancer, miRNAs have demonstrated their value in assisting in diagnosis of recurrence, monitoring progression, and predicting treatment response. ${ }^{157,159,160}$ Their roles can be divided by their associations with cell proliferation, apoptosis, invasion and metastasis, epithelialmesenchymal transition, cancer stemness, and AR status. ${ }^{161}$ Upregulation of miR-96, $-182,182 *-183$, $-375,32,-26 a,-181 a,-93,-196 a,-25,-92$ and let-7i and downregulation of $m i R-16,-31,-125 b,-145,-149$, $-181 b,-184,-205,-221$ and -222 have been confirmed in prostate cancer tissue. ${ }^{162,163}$ It has also been found that miRNA expression alterations occur during the development of CRPC. ${ }^{164}$ In a study analyzing the differential expression of seven miRNAs (miR-221, -222, $-23 \mathrm{~b}$, $-27 \mathrm{~b},-15 \mathrm{a},-16-1$, and -203$)$ across different types of 
benign prostate and prostate cancer samples, found that $\sim 90 \%$ of the analyzed metastatic CRPC tumors could be characterized by the increased miR-221/-222 expression and the downregulated miR-23b/-27b expression. ${ }^{164}$ In addition, as previously mentioned AR splice variants increase in expression during progression to CRPC. ARV7 is the most common AR splice variant with resistance to enzalutamide and abiraterone because of androgenindependent proliferation of prostate cancer cells associated with high levels of AR-V7 in circulating prostate cancer cells. ${ }^{165}$ Several miRNAs (miR-21, $-31,-34 a$, let-7c, -124 , $-205,-185,488^{*}$ and so on) have been reported to regulate
AR and AR splice variants expression. ${ }^{161}$ In addition, another miRNA miR-125b has been found to directly target previously mentioned AR corepressor NcoR 2, subsequently activating AR signaling. ${ }^{166}$ miRNAs may also have therapeutic implications. Lin et al identified two microRNA mimics-miR-217 and miR-181b-5p, which substantially enhance the docetaxel and cabazitaxel sensitivity of CRPC cell lines. ${ }^{167}$ An observational prospective study investigating the plasmatic levels of miRNA according to AR-V7 mutational status in metastatic CRPC patients receiving standard of care therapy is currently recruiting (NCT04188275).

Table I Nonandrogen-Dependent Mechanisms in CRPC

\begin{tabular}{|c|c|c|c|}
\hline Pathway & Mechanisms for Castrate Resistance & $\begin{array}{l}\text { Potential } \\
\text { Therapeutic } \\
\text { Agent }\end{array}$ & Ongoing/Recent Clinical/Preclinical Studies \\
\hline \multirow{3}{*}{$\begin{array}{l}\text { FGF } \\
\text { pathway }\end{array}$} & Overexpression of FGFRI & \multirow{3}{*}{$\begin{array}{l}\text { Dovitinib (FGFR } \\
\text { inhibitor) }\end{array}$} & \multirow{3}{*}{$\begin{array}{l}\text { Phase II study of dovitinib in patients with CRPC after } \\
\text { failure of docetaxel based chemotherapy } \\
(\text { NCTOI74III } 6)^{168}\end{array}$} \\
\hline & $\begin{array}{l}\text { Loss of FGFRIIIB or its alternative splicing to FGFR2IIIc } \\
\text { facilitates EMT }\end{array}$ & & \\
\hline & $\begin{array}{l}\text { Enhanced FGFIO expression leads to paracrine } \\
\text { mesenchymal AR signaling }\end{array}$ & & \\
\hline \multirow{3}{*}{$\begin{array}{l}\text { TGF- } \beta \\
\text { pathway }\end{array}$} & Overexpression of TGF- $\beta$ I and TGF $\beta$ III & \multirow{3}{*}{$\begin{array}{l}\text { Galunisertib } \\
\text { (T } \beta R I \text { inhibitor) }\end{array}$} & \multirow{3}{*}{$\begin{array}{l}\text { Phase II study of a combination of galunisertib and } \\
\text { enzulatamide in metastatic CRPC (NCT02452008) }{ }^{169}\end{array}$} \\
\hline & Loss of expression of T $\beta R I$ and $T \beta R I I$ receptors & & \\
\hline & Blocked SMAD3 inactivation & & \\
\hline \multirow{2}{*}{$\begin{array}{l}\text { RAS/ } \\
\text { MAPK } \\
\text { pathway }\end{array}$} & MAPK induced c-Myc expression & \multirow{2}{*}{$\begin{array}{l}\text { Trametinib (MEK } \\
\mathrm{I} / 2 \text { inhibitor) }\end{array}$} & \multirow{2}{*}{$\begin{array}{l}\text { Phase II study of trametinib in metastatic CRPC that } \\
\text { has progressed on either enzalutamide or abiraterone } \\
\text { acetate. (NCT0288I242) }\end{array}$} \\
\hline & RalGEF pathway activation & & \\
\hline \multirow{3}{*}{$\begin{array}{l}\text { Wnt- } \beta \\
\text { catenin } \\
\text { signaling } \\
\text { pathway }\end{array}$} & $\beta$ catenin acts as a coactivator of $A R$ & \multirow{3}{*}{$\begin{array}{l}\text { I. CWP23229I, } \\
\text { a small molecule } \\
\beta \text {-catenin inhibitor } \\
\text { 2. Foxy-5- } \\
\text { mimicker of Wnt } \\
5 \text { a protein }\end{array}$} & \multirow{3}{*}{$\begin{array}{l}\text { I. Preclinical study confirmed antitumor activity of } \\
\text { small molecule } \beta \text {-catenin inhibitor in prostate cancer } \\
\text { cell lines and primary cells derived from CRPC } \\
\text { patients }{ }^{171} \\
\text { 2. Ongoing phase Ib dose-escalating study of Foxy } 5 \\
\text { in metastatic breast, colon and prostate cancer } \\
(\mathrm{NCT02655952)})^{172}\end{array}$} \\
\hline & $\begin{array}{l}\text { Induction of FOXA2, SOX2 and MYCN facilitates } \\
\text { neuroendocrine differentiation }\end{array}$ & & \\
\hline & $\begin{array}{l}\text { Induction of transcription factors such as SNAIL, } \\
\text { SLUG and TWIST, downregulation of E-cadherin and } \\
\text { upregulation of N-cadherin promotes EMT }\end{array}$ & & \\
\hline \multirow[t]{3}{*}{$\begin{array}{l}\text { Hedgehog } \\
\text { signaling }\end{array}$} & $\begin{array}{l}\text { Disinhibition of smoothened (Smo) leading to } \\
\text { upregulation Gli family proteins (Gli I\&2) }\end{array}$ & \multirow[t]{3}{*}{$\begin{array}{l}\text { Vismodegib (Smo } \\
\text { antagonist) }\end{array}$} & \multirow[t]{3}{*}{$\begin{array}{l}\text { A pharmacodynamic study of vismodegib in men with } \\
\text { metastatic CRPC (NCT02 II } 5828)^{173}\end{array}$} \\
\hline & Gli family proteins interact with AR at its Tau5 domain & & \\
\hline & $\begin{array}{l}\text { Promotion of angiogenesis by upregulating } \\
\text { angiopoietin-I and downregulating angiopoietin-2 }\end{array}$ & & \\
\hline \multirow{3}{*}{$\begin{array}{l}\text { JAK/STAT } \\
\text { pathway }\end{array}$} & Overexpression of IL-6 & \multirow{3}{*}{$\begin{array}{l}\text { Galiellalactone } \\
\text { (STAT3 DNA- } \\
\text { binding inhibitor) }\end{array}$} & \multirow{3}{*}{$\begin{array}{l}\text { Preclinical study showed that galiellalactone inhibits } \\
\text { the STAT3/AR signaling axis and suppresses } \\
\text { enzalutamide-resistant prostate cancer }{ }^{174}\end{array}$} \\
\hline & $\begin{array}{l}\text { Constitutive activation of STAT3 and STAT5 that induce } \\
\text { anti-apoptotic genes. }\end{array}$ & & \\
\hline & $\begin{array}{l}\text { STAT3 also colocalizes with AR and induces } \\
\text { transcription of AR target genes }\end{array}$ & & \\
\hline
\end{tabular}




\section{Conclusion}

The natural evolution of PC growth inevitably leads to an androgen ignorant state. At present, CRPC remains a lethal form of prostate cancer with no available treatment to effectively increase patient survival. The development of CRPC entails both androgen-dependent and androgen-independent growth signaling pathways. Understanding such mechanisms and their interaction is of the utmost importance to develop targeted therapies directed against the various pathways that subvert normal restraint on cell growth. While there have been significant advances in our comprehension of AR dependent mechanisms as well as large trials to optimize ADT, a better grasp of the numerous alternative oncogenic pathways is necessary. As emphasized in this review, the latter are complex pathways that act independently, whilst also interacting with each other as well as the AR and may very well represent future targets of treatment once better explored (summarized in Table 1). To be successful in targeting critical pathways driving hormone-independence, therapeutic measures will need to be personalized and tailored based on the type of CRPC and the underlying castration resistance mechanism.

\section{Acknowledgment}

All authors contributed equally to this work.

\section{Disclosure}

Dr Zach Dovey reports he is Medical Director and owner of stock by certificate of shares from MedTech Holdings Ltd, outside the submitted work. The authors report no other conflicts of interest in this work.

\section{References}

1. Huggins C, Hodges CV. Studies on prostatic cancer. I. The effect of castration, of estrogen and androgen injection on serum phosphatases in metastatic carcinoma of the prostate. CA Cancer J Clin. 1972;22 (4):232-240. doi:10.3322/canjclin.22.4.232

2. Hughes IA, Davies JD, Bunch TI, Pasterski V, Mastroyannopoulou K, MacDougall J. Androgen insensitivity syndrome. Lancet. 2012;380 (9851):1419-1428. doi:10.1016/S0140-6736(12)60071-3

3. Shafi AA, Yen AE, Weigel NL. Androgen receptors in hormone-dependent and castration-resistant prostate cancer. Pharmacol Ther. 2013;140(3):223-238. doi:10.1016/j.pharmthera.20 13.07.003

4. Gelmann EP. Molecular biology of the androgen receptor. $J$ Clin Oncol. 2002;20(13):3001-3015. doi:10.1200/JCO.2002.10.018

5. Koochekpour S. Androgen receptor signaling and mutations in prostate cancer. Asian J Androl. 2010;12(5):639-657. doi:10. 1038/aja.2010.89
6. James ND, de Bono JS, Spears MR, et al; STAMPEDE Investigators. Abiraterone for prostate cancer not previously treated with hormone therapy. $N$ Engl J Med. 2017;377(4):338-351. doi:10.1056/NEJMoa1702900

7. Sternberg CN, Fizazi K, Saad F, et al; PROSPER Investigators. Enzalutamide and survival in nonmetastatic, castration-resistant prostate cancer. $N$ Engl J Med. 2020;382(23):2197-2206. doi:10.1056/NEJMoa2003892

8. Harris WP, Mostaghel EA, Nelson PS, Montgomery B. Androgen deprivation therapy: progress in understanding mechanisms of resistance and optimizing androgen depletion [published correction appears in Nat Clin Pract Urol. 2009 Mar;6(3):173]. Nat Clin Pract Urol. 2009;6(2):76-85. doi:10.1038/ncpuro1296

9. Antonarakis ES, Lu C, Wang $\mathrm{H}$, et al. AR-V7 and resistance to enzalutamide and abiraterone in prostate cancer. $N$ Engl $J$ Med. 2014;371(11):1028-1038. doi:10.1056/NEJMoa1315815

10. Saad F, Hotte SJ. Guidelines for the management of castrate-resistant prostate cancer. Can Urol Assoc J. 2010;4 (6):380-384. doi:10.5489/cuaj.10167

11. Cookson MS, Roth BJ, Dahm P, et al. Castration-resistant prostate cancer: AUA Guideline. J Urol. 2013;190(2):429-438. doi:10. 1016/j.juro.2013.05.005

12. Visakorpi T, Hyytinen E, Koivisto P. In vivo amplification of the androgen receptor gene and progression of human prostate cancer. Nat Genet. 1995;9(4):401-406. doi:10.1038/ng0495-401

13. Bubendorf L, Kononen J, Koivisto P, et al. Survey of gene amplifications during prostate cancer progression by high-throughout fluorescence in situ hybridization on tissue microarrays. Cancer Res. 1999;59(4):803-806.

14. Linja MJ, Savinainen KJ, Saramaki OR, Tammela TL, Vessella RL, Visakorpi T. Amplification and overexpression of androgen receptor gene in hormone-refractory prostate cancer. Cancer Res. 2001;61:3550-3555.

15. Wadosky KM, Koochekpour S. Molecular mechanisms underlying resistance to androgen deprivation therapy in prostate cancer. Oncotarget. 2016;7(39):64447-64470. doi:10.18632/oncotarget.10901

16. Chen CD, Welsbie DS, Tran C, et al. Molecular determinants of resistance to antiandrogen therapy. Nat Med. 2004;10(1):33-39. doi: $10.1038 / \mathrm{nm} 972$

17. Van der Steen T, Tindall DJ, Huang H. Posttranslational modification of the androgen receptor in prostate cancer. Int $J$ Mol Sci. 2013;14(7):14833-14859. doi:10.3390/ijms140714833

18. Azad AA, Zoubeidi A, Gleave ME, Chi KN. Targeting heat shock proteins in metastatic castration- resistant prostate cancer. Nat Rev Urol. 2015;12:26-36. doi:10.1038/nrurol.2014.320

19. Hu R, Dunn TA, Wei S, et al. Ligand-independent androgen receptor variants derived from splicing of cryptic exons signify hormone-refractory prostate cancer. Cancer Res. 2009;69:16-22. doi:10.1158/0008-5472.CAN-08-2764

20. Dehm SM, Schmidt LJ, Heemers HV, Vessella RL, Tindall DJ. Splicing of a novel androgen receptor exon generates a constitutively active androgen receptor that mediates prostate cancer therapy resistance. Cancer Res. 2008;68(13):5469-5477. doi:10.1158/0008-5472.CAN-08-0594

21. Scher HI, Fizazi K, Saad F, et al. Increased survival with enzalutamide in prostate cancer after chemotherapy. $N$ Engl $J$ Med. 2012;367:1187-1197. doi:10.1056/NEJMoa1207506

22. de Bono JS, Logothetis CJ, Molina A, et al. Abiraterone and increased survival in metastatic prostate cancer. $N$ Engl J Med. 2011;364:1995-2005. doi:10.1056/NEJMoa1014618

23. Ryan CJ, Smith MR, de Bono JS, et al. Abiraterone in metastatic prostate cancer without previous chemotherapy. $N$ Engl J Med. 2013;368(2):138-148. doi:10.1056/NEJMoa1209096

24. Armstrong CM, Gao AC. Current strategies for targeting the activity of androgen receptor variants. Asian J Urol. 2019;6 (1):42-49. doi:10.1016/j.ajur.2018.07.003 
25. Tan J, Sharief Y, Hamil KG, et al. Dehydroepiandrosterone activates mutant androgen receptors expressed in the androgen-dependent human prostate cancer xenograft CWR22 and LNCaP cells. Mol Endocrinol. 1997;11:450-459. doi:10.1210/mend.11.4.9906

26. Watson PA, Arora VK, Sawyers CL. Emerging mechanisms of resistance to androgen receptor inhibitors in prostate cancer. Nat Rev Cancer. 2015;15(12):701-711. doi:10.1038/nrc4016

27. Suzuki H, Akakura K, Komiya A, Aida S, Akimoto S, Shimazaki SJ. Codon 877 mutation in the androgen receptor gene in advanced prostate cancer: relation to antiandrogen withdrawal syndrome. Prostate. 1996;29(3):153-158. doi:10.1002/1097-0045(199609) 29:3<153::AID-PROS2990290303>3.0.CO;2-5

28. Suzuki H, Sato N, Watabe Y, Masai M, Seino S, Shimazaki J. Androgen receptor gene mutations in human prostate cancer. J Steroid Biochem Mol Biol. 1993;46(6):759-765. doi:10.1016/ 0960-0760(93)90316-O

29. Gaddipati JP, McLeod DG, Heidenberg HB, et al. Frequent detection of codon 877 mutation in the androgen receptor gene in advanced prostate cancers. Cancer Res. 1994;54(11):2861-2864.

30. Joseph JD, Lu N, Qian J, et al. A clinically relevant androgen receptor mutation confers resistance to second-generation antiandrogens enzalutamide and ARN-509. Cancer Discov. 2013;3 (9):1020-1029. doi:10.1158/2159-8290.CD-13-0226

31. Coffey K, Robson CN. Regulation of the androgen receptor by post-translational modifications. $J$ Endocrinol. 2012;215 (2):221-237. doi:10.1530/JOE-12-0238

32. Wen S, Niu Y, Huang H. Posttranslational regulation of androgen dependent and independent androgen receptor activities in prostate cancer. Asian J Urol. 2020;7(3):203-218. doi:10.1016/j. ajur.2019.11.001

33. Egan A, Dong Y, Zhang H, Qi Y, Balk SP, Sartor O. Castrationresistant prostate cancer: adaptive responses in the androgen axis. Cancer Treat Rev. 2014;40(3):426-433. doi:10.1016/j.ctrv.2013. 09.011

34. Russo JW, Liu X, Ye H, et al. Phosphorylation of androgen receptor serine 81 is associated with its reactivation in castration-resistant prostate cancer. Cancer Lett. 2018;438: 97-104. doi:10.1016/j.canlet.2018.09.014

35. McCall P, Adams CE, Willder JM, et al. Androgen receptor phosphorylation at serine 308 and serine 791 predicts enhanced survival in castrate resistant prostate cancer patients. Int $J \mathrm{Mol}$ Sci. 2013;14(8):16656-16671. doi:10.3390/ijms140816656

36. Qi J, Tripathi M, Mishra R, et al. The E3 ubiquitin ligase siah2 contributes to castration-resistant prostate cancer by regulation of androgen receptor transcriptional activity. Cancer Cell. 2013;23 (3):332-346. doi:10.1016/j.ccr.2013.02.016

37. Hermanson O, Glass CK, Rosenfeld MG. Nuclear receptor coregulators: multiple modes of modification. Trends Endocrinol Metab. 2002;13(2):55-60. doi:10.1016/S1043-2760(01)00527-6

38. Heemers HV, Tindall DJ. Androgen receptor (AR) coregulators: a diversity of functions converging on and regulating the AR transcriptional complex. Endocr Rev. 2007;28(7):778-808.

39. Wolf IM, Heitzer MD, Grubisha M, DeFranco DB. Coactivators and nuclear receptor transactivation. $J$ Cell Biochem. 2008;104 (5):1580-1586. doi:10.1002/jcb.21755

40. Culig Z. Androgen receptor coactivators in regulation of growth and differentiation in prostate cancer. $J$ Cell Physiol. 2016;231 (2):270-274. doi:10.1002/jcp.25099

41. Feng Q, He B. Androgen receptor signaling in the development of castration-resistant prostate cancer. Front Oncol. 2019;9:858. doi: $10.3389 /$ fonc. 2019.00858

42. Jin L, Garcia J, Chan E, et al. Therapeutic targeting of the CBP/ p300 bromodomain blocks the growth of castration-resistant prostate cancer. Cancer Res. 2017;77(20):5564-5575. doi:10.1158/ 0008-5472.CAN-17-0314
43. Nakka M, Agoulnik IU, Weigel NL. Targeted disruption of the p160 coactivator interface of androgen receptor (AR) selectively inhibits AR activity in both androgen-dependent and castration-resistant AR-expressing prostate cancer cells. Int J Biochem Cell Biol. 2013;45(4):763-772. doi:10.1016/j. biocel.2012.12.012

44. He B, Lanz RB, Fiskus W, et al. GATA2 facilitates steroid receptor coactivator recruitment to the androgen receptor complex. Proc Natl Acad Sci U S A. 2014;111(51):18 261-18266. doi:10.1073/pnas.1421415111

45. Taylor BS, Schultz N, Hieronymus H, et al. Integrative genomic profiling of human prostate cancer. Cancer Cell. 2010;18 (1):11-22. doi:10.1016/j.ccr.2010.05.026

46. Xu J, Wu RC, O’Malley BW. Normal and cancer-related functions of the p160 steroid receptor co-activator (SRC) family. Nat Rev Cancer. 2009;9(9):615-630. doi:10.1038/nrc2695

47. Senapati D, Kumari S, Heemers HV. Androgen receptor co-regulation in prostate cancer. Asian J Urol. 2020;7 (3):219-232. doi:10.1016/j.ajur.2019.09.005

48. Azevedo A, Cunha V, Teixeira AL, Medeiros R. IL-6/IL-6R as a potential key signaling pathway in prostate cancer development. World J Clin Oncol. 2011;2(12):384-396. doi:10.5306/wjco.v2. i12.384

49. Culig Z. Role of the androgen receptor axis in prostate cancer. Urology. 2003;62(5 Suppl 1):21-26. doi:10.1016/S0090-4295(03) 00698-8

50. Culig Z, Hobisch A, Cronauer MV, et al. Androgen receptor activation in prostatic tumor cell lines by insulin-like growth factor-I, keratinocyte growth factor, and epidermal growth factor. Cancer Res. 1994;54(20):5474-5478.

51. Sharma J, Gray KP, Evan C, et al. Elevated insulin-like growth factor binding protein-1 (IGFBP-1) in men with metastatic prostate cancer starting androgen deprivation therapy (ADT) is associated with shorter time to castration resistance and overall survival. Prostate. 2014;74(3):225-234. doi:10.1002/ pros. 22744

52. Sharifi N, Auchus RJ. Steroid biosynthesis and prostate cancer. Steroids. 2012;77(7):719-726. doi:10.1016/j.steroids.2012.03. 015

53. Titus MA, Gregory CW, Ford OH 3rd, Schell MJ, Maygarden SJ, Mohler JL. Steroid 5alpha-reductase isozymes I and II in recurrent prostate cancer. Clin Cancer Res. 2005;11 (12):4365-4371.

54. Nishiyama T, Hashimoto Y, Takahashi K. The influence of androgen deprivation therapy on dihydrotestosterone levels in the prostatic tissue of patients with prostate cancer. Clin Cancer Res. 2004;10(21):7121-7126. doi:10.1158/1078-0432. CCR-04-0913

55. Montgomery RB, Mostaghel EA, Vessella R, et al. Maintenance of intratumoral androgens in metastatic prostate cancer: a mechanism for castration-resistant tumor growth. Cancer Res. 2008;68(11):4447-4454. doi:10.1158/0008-5472.CAN-08-0249

56. Liu C, Lou $\mathrm{W}$, Zhu Y, et al. Intracrine androgens and AKR1C3 activation confer resistance to enzalutamide in prostate cancer. Cancer Res. 2015;75(7):1413-1422. doi:10.1158/0008-5472.CAN14-3080

57. Abate-Shen C, Shen MM. FGF signaling in prostate tumorigenesis--new insights into epithelial-stromal interactions. Cancer Cell. 2007;12(6):495-497. doi:10.1016/j.ccr.2007.11.021

58. Lin Y, Wang F. FGF signalling in prostate development, tissue homoeostasis and tumorigenesis. Biosci Rep. 2010;30 (5):285-291. doi:10.1042/BSR20100020

59. Thomson AA. Role of androgens and fibroblast growth factors in prostatic development. Reproduction. 2001;121(2):187-195. doi:10.1530/rep.0.1210187 
60. Memarzadeh S, Xin L, Mulholland DJ, et al. Enhanced paracrine FGF10 expression promotes formation of multifocal prostate adenocarcinoma and an increase in epithelial androgen receptor. Cancer Cell. 2007;12(6):572-585. doi:10.1016/j.ccr.2007.11.002

61. Powers CJ, McLeskey SW, Wellstein A. Fibroblast growth factors, their receptors and signaling. Endocr Relat Cancer. 2000;7 (3):165-197. doi:10.1677/erc.0.0070165

62. Thomson AA, Foster BA, Cunha GR. Analysis of growth factor and receptor mRNA levels during development of the rat seminal vesicle and prostate. Development. 1997;124(12):2431-2439. doi:10.1242/dev.124.12.2431

63. Donjacour AA, Thomson AA, Cunha GR. FGF-10 plays an essential role in the growth of the fetal prostate. Dev Biol. 2003;261(1):39-54. doi:10.1016/S0012-1606(03)00250-1

64. Lu W, Luo Y, Kan M, McKeehan WL. Fibroblast growth factor-10. A second candidate stromal to epithelial cell andromedin in prostate [published correction appears in J Biol Chem 1999 Sep 24;274(39):28058]. J Biol Chem. 1999;274(18):12 827-12834. doi:10.1074/jbc.274.18.12827

65. Ozen M, Giri D, Ropiquet F, Mansukhani A, Ittmann M. Role of fibroblast growth factor receptor signaling in prostate cancer cell survival. J Natl Cancer Inst. 2001;93(23):1783-1790. doi:10. 1093/jnci/93.23.1783

66. Miki T, Bottaro DP, Fleming TP, et al. Determination of ligand-binding specificity by alternative splicing: two distinct growth factor receptors encoded by a single gene. Proc Nat Acad Sci U S A. 1992;89(1):246-250. doi:10.1073/pnas.89.1.246

67. Yan G, Fukabori Y, McBride G, Nikolaropolous S, McKeehan WL. Exon switching and activation of stromal and embryonic fibroblast growth factor (FGF)-FGF receptor genes in prostate epithelial cells accompany stromal independence and malignancy. Mol Cell Biol. 1993;13(8):4513-4522. doi:10.1128/ mcb.13.8.4513-4522.1993

68. Naimi B, Latil A, Fournier G, Mangin P, Cussenot O, Berthon P. Down-regulation of (IIIb) and (IIIc) isoforms of fibroblast growth factor receptor 2 (FGFR2) is associated with malignant progression in human prostate. Prostate. 2002;52(3):245-252. doi:10.1002/pros. 10104

69. Zavadil J, Böttinger EP. TGF-beta and epithelial-to-mesenchymal transitions. Oncogene. 2005;24(37):5764-5774. doi:10.1038/sj. onc. 1208927

70. Stone RC, Pastar I, Ojeh N, et al. Epithelial-mesenchymal transition in tissue repair and fibrosis. Cell Tissue Res. 2016;365 (3):495-506. doi:10.1007/s00441-016-2464-0

71. Yan C, Grimm WA, Garner WL, et al. Epithelial to mesenchymal transition in human skin wound healing is induced by tumor necrosis factor-alpha through bone morphogenic protein-2. Am $J$ Pathol. 2010;176(5):2247-2258. doi:10.2353/ajpath.2010.09 0048

72. Acevedo VD, Gangula RD, Freeman KW, et al. Inducible FGFR-1 activation leads to irreversible prostate adenocarcinoma and an epithelial-to-mesenchymal transition. Cancer Cell. 2007;12(6):559-571. doi:10.1016/j.ccr.2007.11.004

73. Derynck R, Akhurst RJ, Balmain A. TGF-beta signaling in tumor suppression and cancer progression [published correction appears in Nat Genet 2001 Nov;29(3):351]. Nat Genet. 2001;29 (2):117-129.

74. Wikström P, Stattin P, Franck-Lissbrant I, Damber JE, Bergh A. Transforming growth factor betal is associated with angiogenesis, metastasis, and poor clinical outcome in prostate cancer. Prostate. 1998;37(1):19-29. doi:10.1002/(SICI)1097-0045(19980915) $37: 1<19::$ AID-PROS4>3.0.CO;2-3

75. Iruela-Arispe ML, Sage EH. Endothelial cells exhibiting angiogenesis in vitro proliferate in response to TGF-beta 1. J Cell Biochem. 1993;52(4):414-430. doi:10.1002/jcb.240520406
76. Ruscetti F, Varesio L, Ochoa A, Ortaldo J. Pleiotropic effects of transforming growth factor-beta on cells of the immune system. Ann N Y Acad Sci. 1993;685:488-500. doi:10.1111/j.17496632.1993.tb35911.x

77. Welch DR, Fabra A, Nakajima M. Transforming growth factor beta stimulates mammary adenocarcinoma cell invasion and metastatic potential. Proc Natl Acad Sci U S A. 1990;87 (19):7678-7682. doi:10.1073/pnas.87.19.7678

78. Steiner MS, Zhou ZZ, Tonb DC, Barrack ER. Expression of transforming growth factor-beta 1 in prostate cancer. Endocrinology. 1994;135(5):2240-2247. doi:10.1210/endo.135. 5.7956947

79. Derynck R, Zhang YE. Smad-dependent and smad-independent pathways in TGF-beta family signalling. Nature. 2003;425 (6958):577-584. doi:10.1038/nature02006

80. Ornitz DM, Itoh N. Fibroblast growth factors. Genome Biol. 2001;2 (3):REVIEWS3005. doi:10.1186/gb-2001-2-3-reviews3005

81. Jones $\mathrm{E}, \mathrm{Pu} \mathrm{H}$, Kyprianou N. Targeting TGF-beta in prostate cancer: therapeutic possibilities during tumor progression. Expert Opin Ther Targets. 2009;13(2):227-234. doi:10.1517/ 14728220802705696

82. Truong LD, Kadmon D, McCune BK, Flanders KC, Scardino PT, Thompson TC. Association of transforming growth factor-beta 1 with prostate cancer: an immunohistochemical study. Hum Pathol. 1993;24(1):4-9. doi:10.1016/0046-8177(93)90055-L

83. Steiner MS, Anthony CT, Metts J, Moses HL. Prostate cancer cells lose their sensitivity to TGF $\beta$ I growth inhibition with tumor progression. Urol Oncol. 1995;1(6):252-262. doi:10.1016/10781439(96)00028-2

84. Song K, Wang H, Krebs TL, Kim SJ, Danielpour D. Androgenic control of transforming growth factor-beta signaling in prostate epithelial cells through transcriptional suppression of transforming growth factor-beta receptor II. Cancer Res. 2008;68 (19):8173-8182. doi:10.1158/0008-5472.CAN-08-2290

85. Song K, Wang H, Krebs TL, Danielpour D. Novel roles of Akt and mTOR in suppressing TGF-beta/ALK5-mediated smad3 activation. EMBO J. 2006;25(1):58-69. doi:10.1038/sj.emboj.7600917

86. Jiao J, Wang S, Qiao R, et al. Murine cell lines derived from Pten null prostate cancer show the critical role of PTEN in hormone refractory prostate cancer development. Cancer Res. 2007;67 (13):6083-6091. doi:10.1158/0008-5472.CAN-06-4202

87. Schlessinger J, Ullrich A. Growth factor signaling by receptor tyrosine kinases. Neuron. 1992;9(3):383-391. doi:10.1016/08966273(92)90177-F

88. Lee YF, Lin WJ, Huang J, et al. Activation of mitogen-activated protein kinase pathway by the antiandrogen hydroxyflutamide in androgen receptor-negative prostate cancer cells. Cancer Res. 2002;62(21):6039-6044

89. Rybak AP, Bristow RG, Kapoor A. Prostate cancer stem cells: deciphering the origins and pathways involved in prostate tumorigenesis and aggression. Oncotarget. 2015;6(4):1900-1919. doi:10.18632/oncotarget.2953

90. Gioeli D, Mandell JW, Petroni GR, Frierson HF Jr, Weber MJ. Activation of mitogen-activated protein kinase associated with prostate cancer progression. Cancer Res. 1999;59(2):279-284.

91. Hong SK, Kim JH, Lin MF, Park JI. The Raf/MEK/extracellular signal-regulated kinase $1 / 2$ pathway can mediate growth inhibitory and differentiation signaling via androgen receptor downregulation in prostate cancer cells. Exp Cell Res. 2011;317 (18):2671-2682. doi:10.1016/j.yexcr.2011.08.008

92. Mulholland DJ, Kobayashi N, Ruscetti M, et al. Pten loss and RAS/MAPK activation cooperate to promote EMT and metastasis initiated from prostate cancer stem/progenitor cells. Cancer Res. 2012;72(7):1878-1889. doi:10.1158/0008-5472.CAN-11-3132 
93. Lamouille S, Xu J, Derynck R. Molecular mechanisms of epithelial-mesenchymal transition. Nat Rev Mol Cell Biol. 2014;15(3):178-196.

94. Wang J, Kobayashi T, Floc'h N, et al. B-Raf activation cooperates with PTEN loss to drive c-Myc expression in advanced prostate cancer. Cancer Res. 2012;72(18):4765-4776. doi:10.1158/00085472.CAN-12-0820

95. Rybak AP, Ingram AJ, Tang D. Propagation of human prostate cancer stem-like cells occurs through EGFR-mediated ERK activation. PLoS One. 2013;8(4):e61716. doi:10.1371/journal. pone. 0061716

96. Yin J, Pollock C, Tracy K, et al. Activation of the RalGEF/Ral pathway promotes prostate cancer metastasis to bone. Mol Cell Biol. 2007;27(21):7538-7550. doi:10.1128/MCB.00955-07

97. Bakin RE, Gioeli D, Bissonette EA, Weber MJ. Attenuation of Ras signaling restores androgen sensitivity to hormone-refractory C4-2 prostate cancer cells. Cancer Res. 2003;63(8):1975-1980.

98. Chen G, Shukeir N, Potti A, et al. Up-regulation of Wnt-1 and beta-catenin production in patients with advanced metastatic prostate carcinoma: potential pathogenetic and prognostic implications. Cancer. 2004;101(6):1345-1356. doi:10.1002/cncr.20518

99. Kypta RM, Waxman J. Wnt/ $\beta$-catenin signalling in prostate cancer. Nat Rev Urol. 2012;9(8):418-428. doi:10.1038/nrurol.2012.116

100. Murillo-Garzón V, Kypta R. WNT signalling in prostate cancer. Nat Rev Urol. 2017;14(11):683-696. doi:10.1038/nrurol.2017.144

101. Wan X, Liu J, Lu JF, et al. Activation of $\beta$-catenin signaling in androgen receptor-negative prostate cancer cells. Clin Cancer Res. 2012;18(3):726-736. doi:10.1158/1078-0432.CCR-11-2521

102. de la Taille A, Rubin MA, Chen MW, et al. Beta-catenin-related anomalies in apoptosis-resistant and hormone-refractory prostate cancer cells. Clin Cancer Res. 2003;9(5):1801-1807.

103. Kam Y, Quaranta V. Cadherin-bound beta-catenin feeds into the Wnt pathway upon adherens junctions dissociation: evidence for an intersection between beta-catenin pools. PLoS One. 2009;4(2): e4580. doi:10.1371/journal.pone.0004580

104. Shang $\mathrm{S}, \mathrm{Hua} \mathrm{F}, \mathrm{Hu} \mathrm{ZW}$. The regulation of $\beta$-catenin activity and function in cancer: therapeutic opportunities. Oncotarget. 2017;8 (20):33972-33989. doi:10.18632/oncotarget.15687

105. Wang G, Wang J, Sadar MD. Crosstalk between the androgen receptor and beta-catenin in castrate-resistant prostate cancer. Cancer Res. 2008;68(23):9918-9927. doi:10.1158/0008-5472.CAN-08-1718

106. Schweizer L, Rizzo CA, Spires TE, et al. The androgen receptor can signal through Wnt/beta-catenin in prostate cancer cells as an adaptation mechanism to castration levels of androgens. $B M C$ Cell Biol. 2008;9:4. doi:10.1186/1471-2121-9-4

107. Li Y, Wang L, Zhang M, et al. LEF1 in androgen-independent prostate cancer: regulation of androgen receptor expression, prostate cancer growth, and invasion. Cancer Res. 2009;69 (8):3332-3338. doi:10.1158/0008-5472.CAN-08-3380

108. Yu X, Wang Y, Jiang M, et al. Activation of beta-catenin in mouse prostate causes HGPIN and continuous prostate growth after castration. Prostate. 2009;69(3):249-262. doi:10.1002/pros.20877

109. Yu X, Wang Y, DeGraff DJ, Wills ML, Matusik RJ. Wnt/Bcatenin activation promotes prostate tumor progression in a mouse model. Oncogene. 2011;30(16):1868-1879. doi:10.10 38/onc. 2010.560

110. Yang X, Chen MW, Terry S, et al. Complex regulation of human androgen receptor expression by Wnt signaling in prostate cancer cells [published correction appears in oncogene. $2006 \mathrm{Jul}$ 13;25(30):4256]. Oncogene. 2006;25(24):3436-3444. doi:10. 1038/sj.onc. 1209366

111. Ciarlo M, Benelli R, Barbieri O, et al. Regulation of neuroendocrine differentiation by AKT/hnRNPK/AR/ $\beta$-catenin signaling in prostate cancer cells [published correction appears in Int J Cancer. 2014 Nov 1;135(9):E9]. Int $J$ Cancer. 2012;131(3):582-590. doi:10.1002/ijc.26402
112. Wielenga VJ, Smits R, Korinek V, et al. Expression of CD44 in Apc and Tcf mutant mice implies regulation by the WNT pathway. Am J Pathol. 1999;154(2):515-523. doi:10.1016/ S0002-9440(10)65297-2

113. Mu P, Zhang Z, Benelli M, et al. SOX2 promotes lineage plasticity and antiandrogen resistance in TP53- and RB1-deficient prostate cancer. Science. 2017;355(6320):84-88. doi:10.1126/ science.aah4307

114. Qi J, Nakayama K, Cardiff RD, et al. Siah2-dependent concerted activity of HIF and FoxA2 regulates formation of neuroendocrine phenotype and neuroendocrine prostate tumors. Cancer Cell. 2010;18(1):23-38. doi:10.1016/j.ccr.2010.05.024

115. Yang X, Chen MW, Terry S, et al. A human- and male-specific protocadherin that acts through the wnt signaling pathway to induce neuroendocrine transdifferentiation of prostate cancer cells. Cancer Res. 2005;65(12):5263-5271. doi:10.1158/00085472.CAN-05-0162

116. Wu ZQ, Li XY, Hu CY, Ford M, Kleer CG, Weiss SJ. Canonical Wnt signaling regulates slug activity and links epithelial-mesenchymal transition with epigenetic Breast Cancer 1, Early Onset (BRCA1) repression. Proc Natl Acad Sci U S A. 2012;109(41):16654-16659. doi:10.1073/pnas.1205822109

117. Howe LR, Watanabe O, Leonard J, Brown AM. Twist is up-regulated in response to Wnt1 and inhibits mouse mammary cell differentiation. Cancer Res. 2003;63(8):1906-1913.

118. Conacci-Sorrell M, Simcha I, Ben-Yedidia T, Blechman J, Savagner P, Ben-Ze'ev A. Autoregulation of E-cadherin expression by cadherin-cadherin interactions: the roles of beta-catenin signaling, slug, and MAPK. J Cell Biol. 2003;163(4):847-857. doi: $10.1083 /$ jcb. 200308162

119. Crawford HC, Fingleton BM, Rudolph-Owen LA, et al. The metalloproteinase matrilysin is a target of beta-catenin transactivation in intestinal tumors. Oncogene. 1999;18(18):2883-2891. doi:10.1038/sj.onc. 1202627

120. Zhang K, Guo Y, Wang X, et al. WNT/ $\beta$-catenin directs selfrenewal symmetric cell division of hTERThigh prostate cancer stem cells. Cancer Res. 2017;77(9):2534-2547. doi:10.1158/ 0008-5472.CAN-16-1887

121. Vokes SA, Ji H, Wong WH, McMahon AP. A genome-scale analysis of the cis-regulatory circuitry underlying sonic hedgehog-mediated patterning of the mammalian limb. Genes Dev. 2008;22:2651-2663. doi:10.1101/gad.1693008

122. Shaw A, Bushman W. Hedgehog signaling in the prostate. J Urol. 2007;177:832-838. doi:10.1016/j.juro.2006.10.061

123. Shaw G, Price AM, Ktori E, et al. Hedgehog signalling in androgen independent prostate cancer. Eur Urol. 2008;54 (6):1333-1343. doi:10.1016/j.eururo.2008.01.070

124. Lee SW, Moskowitz MA, Sims JR. Sonic hedgehog inversely regulates the expression of angiopoietin-1 and angiopoietin-2 in fibroblasts. Int J Mol Med. 2007;19(3):445-451.

125. Karhadkar SS, Bova GS, Abdallah N, et al. Hedgehog signalling in prostate regeneration, neoplasia and metastasis. Nature. 2004;431(7009):707-712. doi:10.1038/nature02962

126. Suzman DL, Antonarakis ES. Clinical implications of hedgehog pathway signaling in prostate cancer. Cancers. 2015;7 (4):1983-1993. doi:10.3390/cancers7040871

127. Quaglia F, Krishn SR, Wang Y, et al. Differential expression of $\alpha \mathrm{V} \beta 3$ and $\alpha \mathrm{V} \beta 6$ integrins in prostate cancer progression. PLoS One. 2021;16(1):e0244985. doi:10.1371/journal.pone.0244985

128. Goel HL, Li J, Kogan S, Languino LR. Integrins in prostate cancer progression. Endocr Relat Cancer. 2008;15(3):657-664. doi:10.1677/ERC-08-0019

129. Cress AE, Rabinovitz I, Zhu W, Nagle RB. The alpha 6 beta 1 and alpha 6 beta 4 integrins in human prostate cancer progression. Cancer Metastasis Rev. 1995;14(3):219-228. doi:10.1007/ BF00690293 
130. Lu H, Wang $\mathrm{T}$, Li J, et al. $\alpha v \beta 6$ integrin promotes castrateresistant prostate cancer through JNK1-mediated activation of androgen receptor. Cancer Res. 2016;76(17):5163-5174. doi:10.1158/0008-5472.CAN-16-0543

131. Juan-Rivera MC, Martínez-Ferrer M. Integrin inhibitors in prostate cancer. Cancers. 2018;10(2):44. doi:10.3390/cancers1002 0044

132. Shishodia G, Koul S, Koul HK. Protocadherin 7 is overexpressed in castration resistant prostate cancer and promotes aberrant MEK and AKT signaling. Prostate. 2019;79(15):1739-1751. doi:10. 1002/pros.23898

133. Ni J, Cozzi P, Hao J, et al. Epithelial cell adhesion molecule (EpCAM) is associated with prostate cancer metastasis and chemo/radioresistance via the $\mathrm{PI} 3 \mathrm{~K} / \mathrm{Akt} / \mathrm{mTOR}$ signaling pathway. Int $J$ Biochem Cell Biol. 2013;45(12):2736-2748. doi:10.1016/j.biocel.2013.09.008

134. Jansson KH, Lynch JE, Lepori-Bui N, Czymmek KJ, Duncan RL, Sikes RA. Overexpression of the VSSC-associated CAM, $\beta-2$, enhances $\mathrm{LNCaP}$ cell metastasis associated behavior. Prostate. 2012;72(10):1080-1092. doi:10.1002/pros.21512

135. Daaka Y. G proteins in cancer: the prostate cancer paradigm. $S c i$ STKE. 2004;2004(216):re2. doi:10.1126/stke.2162004re2

136. Wang W, Chen ZX, Guo DY, Tao YX. Regulation of prostate cancer by hormone-responsive $\mathrm{G}$ protein-coupled receptors. Pharmacol Ther. 2018;191:135-147. doi:10.1016/j. pharmthera.2018.06.005

137. Pinski J, Xiong S, Wang Q, Stanczyk F, Hawes D, Liu SV. Effect of luteinizing hormone on the steroidogenic pathway in prostate cancer. Prostate. 2011;71(8):892-898. doi:10.1002/pros.21305

138. Golbano JM, Lóppez-Aparicio P, Recio MN, Pérez-Albarsanz MA. Finasteride induces apoptosis via Bcl-2, Bcl-xL, Bax and caspase-3 proteins in $\mathrm{LNCaP}$ human prostate cancer cell line. Int J Oncol. 2008;32(4):919-924.

139. Huynh H. Induction of apoptosis in rat ventral prostate by finasteride is associated with alteration in MAP kinase pathways and Bcl-2 related family of proteins. Int $J$ Oncol. 2002;20 (6):1297-1303.

140. Shankar S, Srivastava RK. Involvement of Bcl-2 family members, phosphatidylinositol 3 -kinase/AKT and mitochondrial p53 in curcumin (diferulolylmethane)-induced apoptosis in prostate cancer. Int J Oncol. 2007;30(4):905-918.

141. Radu A, Pichon C, Camparo P, et al. Expression of follicle-stimulating hormone receptor in tumor blood vessels. $N$ Engl $J$ Med. 2010;363(17):1621-1630. doi:10.1056/ NEJMoa1001283

142. Feng S, Agoulnik IU, Bogatcheva NV, et al. Relaxin promotes prostate cancer progression. Clin Cancer Res. 2007;13 (6):1695-1702. doi:10.1158/1078-0432.CCR-06-2492

143. Thompson VC, Hurtado-Coll A, Turbin D, et al. Relaxin drives Wnt signaling through upregulation of PCDHY in prostate cancer. Prostate. 2010;70(10):1134-1145. doi:10.1002/pros.21148

144. Wang H, Jones J, Turner T, et al. Clinical and biological significance of KISS1 expression in prostate cancer. Am J Pathol. 2012;180(3):1170-1178. doi:10.1016/j.ajpath.2011.11.020

145. Cassoni P, Ghé C, Marrocco T, et al. Expression of ghrelin and biological activity of specific receptors for ghrelin and des-acyl ghrelin in human prostate neoplasms and related cell lines. Eur J Endocrinol. 2004;150(2):173-184. doi:10.1530/ eje. 0.1500173

146. Nelson JB, Nabulsi AA, Vogelzang NJ, et al. Suppression of prostate cancer induced bone remodeling by the endothelin receptor A antagonist atrasentan. J Urol. 2003;169(3):1143-1149. doi:10.1097/01.ju.0000042162.08938.27

147. Barki-Harrington L, Daaka Y. Bradykinin induced mitogenesis of androgen independent prostate cancer cells. J Urol. 2001;165(6 Pt 1):2121-2125. doi:10.1016/S0022-5347(05)66305-7
148. Tam L, McGlynn LM, Traynor P, Mukherjee R, Bartlett JM, Edwards J. Expression levels of the JAK/STAT pathway in the transition from hormone-sensitive to hormone-refractory prostate cancer. Br J Cancer. 2007;97(3):378-383. doi:10.1038/sj.bjc.6603871

149. Shariat SF, Andrews B, Kattan MW, et al. Plasma levels of interleukin- 6 and its soluble receptor are associated with prostate cancer progression and metastasis. Urology. 2001;58 (6):1008-1015. doi:10.1016/S0090-4295(01)01405-4

150. Lee SO, Lou W, Johnson CS, Trump DL, Gao AC. Interleukin-6 protects $\mathrm{LNCaP}$ cells from apoptosis induced by androgen deprivation through the Stat3 pathway. Prostate. 2004;60(3):178-186. doi: $10.1002 /$ pros. 20045

151. Bishop JL, Thaper D, Zoubeidi A. The multifaceted roles of STAT3 signaling in the progression of prostate cancer. Cancers. 2014;6(2):829-859. doi:10.3390/cancers6020829

152. Lou W, Ni Z, Dyer K, Tweardy DJ, Gao AC. Interleukin-6 induces prostate cancer cell growth accompanied by activation of stat3 signaling pathway. Prostate. 2000;42(3):239-242. doi:10.1002/(SICI)1097-0045(20000215)42:3<239::AIDPROS10>3.0.CO;2-G

153. Frank DA. STAT3 as a central mediator of neoplastic cellular transformation. Cancer Lett. 2007;251(2):199-210. doi:10.1016/j. canlet.2006.10.017

154. Chen J, Jiang CC, Jin L, Zhang XD. Regulation of PD-L1: a novel role of pro-survival signalling in cancer. Ann Oncol. 2016;27(3):409-416. doi:10.1093/annonc/mdv615

155. Akbay EA, Koyama S, Carretero J, et al. Activation of the PD-1 pathway contributes to immune escape in EGFR-driven lung tumors. Cancer Discov. 2013;3(12):1355-1363. doi:10.1158/ 2159-8290.CD-13-0310

156. $\mathrm{Xu} \mathrm{L}$, Chen $\mathrm{X}$, Shen $\mathrm{M}$, et al. Inhibition of IL-6-JAK/Stat3 signaling in castration-resistant prostate cancer cells enhances the NK cell-mediated cytotoxicity via alteration of PD-L1/ NKG2D ligand levels. Mol Oncol. 2018;12(3):269-286. doi:10.1002/1878-0261.12135

157. Doi T, Ishikawa T, Okayama T, et al. The JAK/STAT pathway is involved in the upregulation of PD-L1 expression in pancreatic cancer cell lines. Oncol Rep. 2017;37(3):1545-1554. doi:10.3892/ or.2017.5399

158. Thieu W, Tilki D, de Vere White R, et al. The role of microRNA in castration-resistant prostate cancer. Urol Oncol. 2014;32 (5):517-523. doi:10.1016/j.urolonc.2013.11.004

159. Friedman RC, Farh KK, Burge CB, et al. Most mammalian mRNAs are conserved targets of microRNAs. Genome Res. 2008;19(1):92-105. doi:10.1101/gr.082701.108

160. Cochetti G, Rossi de Vermandois JA, Maulà V, et al. Role of miRNAs in prostate cancer: do we really know everything? Urol Oncol. 2020;38(7):623-635. doi:10.1016/j.urolonc.2020.03.007

161. Kojima S, Goto Y, Naya Y. The roles of microRNAs in the progression of castration-resistant prostate cancer. J Hum Genet. 2017;62(1):25-31. doi:10.1038/jhg.2016.69

162. Volinia S, Calin GA, Liu C-G, et al. A microRNA expression signature of human solid tumors defines cancer gene targets. Proc Natl Acad Sci U S A. 2006;103(7):2257-2261. doi:10.1073/ pnas.0510565103

163. Schaefer A, Jung M, Mollenkopf HJ, et al. Diagnostic and prognostic implications of microRNA profiling in prostate carcinoma. Int $J$ Cancer. 2010;126(5):1166-1176. doi:10.1002/ijc.24827

164. Sun T, Yang $M$, Chen $S$, et al. The altered expression of MiR-221/-222 and MiR-23b/-27b is associated with the development of human castration resistant prostate cancer. Prostate. 2012;72(10):1093-1103. doi:10.1002/pros.22456

165. Shi XB, Ma AH, Xue L, et al. miR-124 and androgen receptor signaling inhibitors repress prostate cancer growth by downregulating androgen receptor splice variants, EZH2, and Src. Cancer Res. 2015;75(24):5309-5317. doi:10.1158/0008-5472.CAN-14-0795 
166. Yang X, Bemis L, Su L-J, et al. miR-125b regulation of androgen receptor signaling via modulation of the receptor complex co-repressor NCOR2. Biores Open Access. 2012;1(2):55-62. doi:10.1089/biores.2012.9903

167. Lin HM, Nikolic I, Yang J, et al. MicroRNAs as potential therapeutics to enhance chemosensitivity in advanced prostate cancer. Sci Rep. 2018;8(7820). doi:10.1038/s41598-018-26050-y

168. Choi YJ, Kim HS, Park SH, et al. Phase II Study of dovitinib in patients with castration-resistant prostate cancer (KCSG-GU11-05). Cancer Res Treat. 2018;50(4):1252-1259. doi:10.4143/crt.2017.438

169. Sidney Kimmel Comprehensive Cancer Center at Johns Hopkins. Study of TGF- $\beta$ receptor inhibitor galunisertib (LY2157299) and enzalutamide in metastatic castration-resistant prostate cancer. NLM identifier: NCT02452008. Available from: https://clinical trials.gov/ct2/show/NCT02452008. Accessed June 8, 2021.

170. Jonsson Comprehensive Cancer Center. Trametinib in treating patients with progressive metastatic hormone-resistant prostate cancer. NLM identifier: NCT02881242. Available from: https:// clinicaltrials.gov/ct2/show/NCT02881242. Accessed June 8, 2021.
171. Pak S, Park S, Kim Y, et al. The small molecule WNT/ $\beta$-catenin inhibitor CWP232291 blocks the growth of castration-resistant prostate cancer by activating the endoplasmic reticulum stress pathway [published correction appears in J Exp Clin Cancer Res. 2019 Oct 31;38(1):440]. J Exp Clin Cancer Res. 2019;38 (1):342. doi:10.1186/s13046-019-1342-5

172. WntResearch AB. Dose escalating study of foxy-5 in breast-, colon- or prostate cancer patients. NLM identifier: NCT02655952. Available from: https://clinicaltrials.gov/ct2/ show/NCT02655952. Accessed June 8, 2021.

173. Sidney Kimmel Comprehensive Cancer Center at Johns Hopkins. A study of vismodegib in men with metastatic CRPC with accessible metastatic lesions for tumor biopsy. NLM identifier: NCT02115828. Available from: https://clinicaltrials.gov/ct2/ show/NCT02115828. Accessed June 8, 2021.

174. Thaper D, Vahid S, Kaur R, et al. Galiellalactone inhibits the STAT3/AR signaling axis and suppresses enzalutamide-resistant prostate cancer. Sci Rep. 2018;8(1):17307. doi:10.1038/s41598018-35612-z

\section{Publish your work in this journal}

Research and Reports in Urology is an international, peer-reviewed, open access journal publishing original research, reports, editorials, reviews and commentaries on all aspects of adult and pediatric urology in the clinic and laboratory including the following topics: Pathology, pathophysiology of urological disease; Investigation and treatment of urological disease; Pharmacology of drugs used for the treatment of urological disease. The manuscript management system is completely online and includes a very quick and fair peer-review system, which is all easy to use. Visit http://www.dovepress.com/ testimonials.php to read real quotes from published authors. 